\title{
PEDAGOGY
}

\section{INTERDISCIPLINARY, MULTIDISCIPLINARY AND TRANSDISCIPLINARY RESEARCH STRATEGY FOR SPEECH DEVELOPMENT OF PRIMARY SCHOOL PUPILS WITH DISGRAPHY}

\author{
${ }^{I}$ Docent Larisa Zhuravlova \\ Ukraine, Melitopol, \\ Bohdan Khmelnitskiy Melitopol State Pedagogical University \\ ${ }^{1}$ PhD, Associate Professor of the Department of Social work, \\ Social Pedagogics and Preschool Education
}

DOI: https://doi.org/10.31435/rsglobal_wos/31012019/6315

\section{ARTICLE INFO}

Received: 10 November 2018

Accepted: 11 January 2019

Published: 31 January 2019

\section{KEYWORDS}

research strategy, primary school education, pupils, disgraphy, speech development.

\begin{abstract}
The article is related to the importance of an interdisciplinary, multidisciplinary and transdisciplinary strategy in teaching children of primary school age with dysgraphia. The research work also shows the relevance solving problems children's complex diagnostics and correction of with dysgraphia using transdisciplinary, multidisciplinary and interdisciplinary researches strategy.
\end{abstract}

Citation: Larisa Zhuravlova. (2019) Interdisciplinary, Multidisciplinary and Transdisciplinary Research Strategy for Speech Development of Primary School Pupils with Disgraphy. International Academy Journal Web of Scholar. 1(31), Vol.2. doi: 10.31435/rsglobal_wos/31012019/6315

Copyright: (C) 2019 Larisa Zhuravlova. This is an open-access article distributed under the terms of the Creative Commons Attribution License (CC BY). The use, distribution or reproduction in other forums is permitted, provided the original author(s) or licensor are credited and that the original publication in this journal is cited, in accordance with accepted academic practice. No use, distribution or reproduction is permitted which does not comply with these terms.

Introduction. For holistic perception and comprehension of the complexity of the world, science has already had enough purely disciplinary approach, and therefore at the disposal of modern scholars there was knowledge, different in its nature: philosophical, scientific (disciplinary and interdisciplinary). It is worth noting that the complication of disciplinary images of objects and subjects of study, which is a development of cognition natural consequence, has created conditions for interdisciplinary interactions, which are now carried out within the framework of interdisciplinary, multidisciplinary and transdisciplinary approaches.

The terms «multidisciplinary research», «cross-disciplinary research», «interdisciplinary research» and «transdisciplinary research» are very popular in the field of sciences methodology. However, in most cases, they are used as synonyms. In this article, we will try to reveal the essence of these concepts and to find out if in reality they are so consonant.

Analysis of recent research. An analysis of recent studies and publications suggests that many foreign scholars have long sought to interpret and distinguish the aforementioned concepts, among which we find the works of T. Ausburg, P. Besselar, F. Bolsinger, V. Gagateka, G. Gamerix, R. Ketter, J. Klein, L. Mita, M. Novak, R. Nordala, S. Serafin and so. The significant work is the work of B. Nicolescu, the president of the International Center for Trans-Systematic Studies, who emphasized the need to build bridges between disciplines through multidisciplinary and interdisciplinary studies [1]. 
Research results. The interdisciplinary approaches are focused not so much on the synthesis of genuine disciplinary knowledge, but on the acquisition of new knowledge about the objects of research due to the search for them in such subject areas. This circumstance allowed using the methodology of one discipline to solve problems of another discipline. At the same time there was a mutual enrichment of these disciplines language and also there was an intensification of their disciplinary methodology.

Another type of interdisciplinary interactions is multidisciplinary approaches, in which the search for a combination of not only similar subject areas, but also those that have no similarity, however, are essential for the knowledge and understanding of the object being studied. In essence, multidisciplinary approaches are the method of expert assessments or the method of expert groups whose success is guaranteed by a consensus of opinions based on the results of disciplinary research and a compromise of experts, which is achieved within the limits of the rules of professional and business ethics.

The meaningful content of the term «transdisciplinary» is variable. According to J. Piaget, who owns the term transdisciplinary, after a phase of interdisciplinary research, one should expect a higher level of transdisciplinarity - a phase that is not limited to interdisciplinary relationships, but places these relationships within the global system, without strict boundaries between disciplines. The transdisciplinary principles are successfully integrated into scientific research today, since references to the «systematic, complex approach, to the adjacent disciplines become, in fact, mandatory for any scholarly work» [2, p. 154-172].

The transdisciplinary approach, which J. Piazhe and E. Yanch consider a new branch of knowledge different from multidisciplinary, is characterized by the desire of researchers to «place disciplinary knowledge about the world, the object of research, their subject areas within a certain global system, without strict boundaries between disciplines» [2].

It is worth noting that in contemporary scientific thought there are diametrically opposed views on the essence of interdisciplinary and transdisciplinary: from their identification to principal opposition. For example, some scholars emphasize that interdisciplinarity is inherent in science from the outset, and therefore it should not be highlighted as a special research principle. Thus, in particular, I. Kasavin notes that «interdisciplinary interaction is a natural state of science» [3, p. 5- 17.]. According to O. Knigin, interdisciplinarity as a principle has no advantages over the dialectical principle of comprehensiveness, criticizing the term itself and pointing out that interdisciplinarity can literally be interpreted as «inter disciplinary», that is, as an analysis of the spheres that are between the intellectual fields of individual disciplines The scientist is convinced that it is more correct to speak about the integration of separate disciplines, because truly new knowledge arises «at the junction» of sciences, and not «between» sciences [4, p. 14-21].

It is quite grounded that the difference between transdisciplinarity and the interdisciplinarity of L. Kiyaschenko and V. Moiseyev is considered, emphasizing that «the situation of interdisciplinary is the situation of transfer of knowledge from one disciplinary area to another while maintaining disciplinary boundaries. In other words, interdisciplinarity methodologically additionally enriches what is defined within the disciplinary limits. The situation of transdisciplinary involves breaking the stiffness of the disciplinary divisions of scientific knowledge, they become «passable», which contributes to the emergence of various systems «on top» of disciplinary boundaries, «between» systemic formations, «extra» systems, etc.» [5, p. 23].

At the same time, analyzing the relation between the concepts of «interdisciplinarity» and «transdisciplinarity», J. Mittelstrass believes that transdisciplinarity is an identical interdisciplinarity, and its main value is that it allows overcoming disciplinary deaf angles [6, p. 17-31]. It should be noted that the supporters of transdisciplinarity, on the contrary, in every way emphasize its fundamental differences from interdisciplinary.

Clarifying these notions, L. Kiyaschenko writes that interdisciplinarity can be said in cases where different disciplines, interacting with each other, form a new discipline (for example, biochemistry or biophysics was formed) or when the theoretical concepts or experimental practices of one disciplinary area penetrate others, using their methodology in solving disciplinary problems there [7, p. 17].Transdisciplinary, according to the scholar, are such cognitive situations in which the scientific research is forced, in search of integrity and its own justification, to "carry out a transcendental shift towards the border with the world of life» [7, p. 18].

An adequately balanced approach to the correlation of these concepts is demonstrated by E. Knyazeva, considering them close in content, but not having certain conceptual delineations. In her 
view, multidisciplinary (or polydisciplinary) can consider such a study in which the object is studied simultaneously from different sides by several scientific disciplines. Each of the disciplines uses its own methodology, its theoretical assumptions, contributes to the "general treasury» of knowledge about the object. Interdisciplinarity involves the cooperation of different knowledge areas, the use of general concepts. Transdisciplinarity is inherent in research that goes «through», "across» the boundaries of many scientific disciplines and beyond their higher level limits that is beyond specific disciplines. Transdisciplinary research is characterized by a holistic vision of the study subject. Such studies are characterized by the transfer of schemes from one disciplinary area to another [8, p. 193-201].

In any case, transdisciplinarity appears as a way of compelled the emergence of scientific knowledge beyond the boundaries of science in the process of global synthesis of world forms comprehension [9, p. 77-86.]. The need for the transcendence of disciplinary knowledge Y. Habermas relates, first of all, to the sciences that «use the reconstructive methodology and rely on the pretheoretical knowledge of subjects competent in their judgments and actions, as well as on the systems of knowledge transmitted by the cultural tradition» [10, p. 27-28].

Each form of transdisciplinarity has its advantages and disadvantages, which are manifested in solving specific problems. However, the feasibility of using transdisciplinarity is obvious, it has been considered one of the main ways of solving the problems of the XXI century. This is evidenced by the text of the World Declaration on Higher Education for the 21st Century: Approaches and Practical Measures. The article 5 and article 6 of this Declaration contain recommendations to encourage the transdisciplinarity of curricula programs and to train future professionals, to use a transdisciplinary approach to address the complex nature and society problems [11].

In turn, in order for transdisciplinarity to become accessible and understandable to teachers, university students, it should be presented in the form of a scientific approach (Transdisciplinary-4). In other words, Transdisciplinarity-4 should be an independent scientific field with its subject of research and conception, transdisciplinary approach and language, units of measurement and models of reality, the method of information analysis and the methodology of risk analysis of the decisions taken. In this context, Transdisciplinary -4 will allow for a general scientific classification and systematization of disciplinary knowledge. After such processing, disciplinary knowledge becomes fully adapted to their joint use in solving scientific and practical problems of any complexity and complexity.

Attempts to eliminate these difficulties originate from Platon and Platin. In their turn, from their conception of the One, the Transdisciplinary-4 is initiated and, accordingly, its transdisciplinary system approach. From the point of view of the transdisciplinary system approach (Transdisciplinarity-4), the World is the only Ordinary Medium (One Orderly Medium). Elements of a unified ordered environment (ESC) are: a set of causes and consequences of its existence; general and private laws and laws; phenomena, objects and processes, as well as their properties, relationships and interactions at any level of reality. Within the framework of this linguistic formula, a single environment act as a single (general) environment. In the context of such an environment, the plurality of fundamentally possible environments, including objects requiring reflection and research, will be considered only as a collection of its natural fragments.

In this context, pedagogical theory and practice, in particular, speech therapy, fall entirely within this definition. The knowledge about how to develop, educate a person is transdisciplinary as pedagogical theory and practice combines the features of philosophy, science, crafts, art, technology, folk wisdom, etc.

According view by M. Zhinkin, speech has its own structural and functional specificity, it is not an ordinary manifestation of language. It is the object of study, not its result. Linguistics in all aspects, physiology in the range of problems associated with the activities of the second signaling system, physics in the acoustics section, logic and, ultimately, psychology - each of these branches of knowledge, going its own ways and roads and fulfilling its particular tasks, has in the sense of the same common language for all these disciplines. The real object of study remains common [12, p. 13].

M. Zhinkin notes that each of the sciences: psychology, linguistics, logic, physiology simulates the same object - speech activity for their own purposes, allocating in it their own, essential characteristics. According to L. Leontiev, the system of categories in which the description of speech activity is carried out must be acceptable to any science that studies it, and not to be constructed within the same science, for example, linguistics, on the basis of a priori consideration [13, p. 57-60]. The developed provisions are of great practical importance, as they contribute to the improvement of existing methods of correctional and restorative learning and the creation of new ones. 
In psychology, the most important opposition is the opposition of the mechanism and process. The combination of physiological and psychological factors predetermines the potential possibility of a certain operation and self-realization of it in the real context of activity, subject to a specific motive and purpose of activity, in the presence of a real object and a real instrument of production.

The knowledge of how to organize a correction process needs an additional combination of medicine and psychology. The process of diagnostics and correction of speech development implies additional orientation, immersion in the educational process.

For linguists, the main thing is the delineation of language as an object and language as a process. The distinction of language as an object and language as an ability has not been sufficiently disseminated in linguistics.

From the point of view of logic, the most important is the distinction between the form of thinking (process) and the form of knowledge (subject), which is completely embedded in this scheme.

From the standpoint of philosophy, the process of theoretical, cognitive activity always involves the unity of three components:

- the object of cognitive activity (the real world and man as part of this world);

- the subject of cognitive activity, which is a carrier of known psychophysiological features, which predetermine specifically human forms of cognition;

- a system of universally significant forms and methods of ideal phenomena external manifestation (system of signs).

From logopedic point of view, the process of correction of speech disorders involves the presence of three components in their combination, which are interrelated and interdependent:

- the object of speech activity (environment and human in this environment);

- the subject of speech activity, which is a carrier of known psychophysiological features that predetermine specific human speech activity;

- the formation of a system of signs, that is, universally significant forms and methods of external manifestation of ideal phenomena.

It is the unity of the aforementioned components that is realized in the correctional process of speech activity.

It is the unity of the aforementioned components that is realized in the correctional process of speech activity.

So, as we see, speech and speaking, as different phenomena, are interconnected and interdependent. In the unity of speech and speaking, the dual nature of language as a human phenomenon is realized, which performs certain functions in a human society, having the appropriate means at its disposal. Speech and speaking are understood as the only human phenomenon, as a certain real sign system, which exists in the collective consciousness of society, in the speech competence of each member of society in the form of a structure.

According to V. Glukhov, speech is a complex functional system, the basis of which is the use of a sign system of language, it operates interindividual, internally individual and intrapsychic [14]. Broadcasting is an important means of communication between a child and the outside world; this is a special and most perfect form of communication, inherent only to human.

According to O. Kornev, the development of speech and speech is an integral part of mental ontogenesis. The structure of the language is closely related to the structure of basic mental processes and behavior.

From the psychological point of view, scientists - L. Vygotsky (1984), O. Leontiev (1997) consider speech, speech behavior as a set of skills necessary for the implementation of communicative behavior.

The totality of speech units, the rules of their combination for constructing the statement, and the psycho-physiological mechanisms for the implementation of speeches in the speech form a functional self-organized system [15].

On the basis of physiology data of VND (the theory of functional systems by P. Anokhin), psycholinguistics (O. Leontiev's theory of speech activity, O. Leontiev's and T. Ahutina's model of generation of speech), neuropsychology (theory and model of $\mathrm{O}$. Luria of the structural and functional organization of the brain as a substrate mental activity) model of the FSMM, presented by the author includes three main subsystems: semiotic, programming and interpretation of speech acts and regulatory. 
According to O. Kornev, the functional system of speech and speaking creates the basic psycho-physiological support for communicative-speech activity. Its system-forming factor is a common task and the result is the creation of statements in the process of speech communication.

Speech is an integral part of many forms of mental activity: as a behavioral act is considered within the psychology of behavior; as a communicative means refers to the psychology of personality, psychology of communication; as a way of acquiring knowledge and form of their categorical expression is cognitive psychology, psychology of cognition; as a form of practical implementation linguistics and psycholinguistics; as a mechanism - psychophysiology and neuropsychology. All of this goes back to the analysis of its ontogenetic aspect, which has a direct relation to the developmental psychology. The foregoing confirms the importance of speech as a specific type of activity in a person life, which is impossible without language and is recognized by a rather complex system of education.

Thus, the question of speech and speaking today is the subject of many scientific discussions, which indicates a constant search and development of views on the problem. Taking into account the systemic connections of speech and speech enables to determine the basic approaches to solving the main correctional and methodological issues of speech development of primary schoolchildren with dysgraphia, which is a complex system that reflects the systemic nature of speech relations in content and methodology.

Consequently, the synthesis of the results of research on the phenomenon of speech provides grounds for considering broadcasting a complex functional system, the basis of which is the use of a sign system of language in the process of communication, without which it is impossible to fully develop the person. This confirms the previously mentioned opinion on the close interaction of speech and speaking.

The analysis of psychologists and psycholinguists (I. Bech, L. Andrusishina, I. Zimnya, V. Polischuk, E. Sobotovich, V. Tarasun, V. Tishchenko) prove that language mastering not only adds something new to the development of the child, but also rebuilds all her psyche and activities.

So, in particular, analyzing the mental development of a child, Zimnya notes that it is carried out simultaneously on several lines, in particular:

- cognitive sphere (the formation of intelligence, the development of knowledge mechanisms);

- psychological structure and content of activity (formation of goals, motives and development of their relations, mastering of methods and means activity);

- personality (orientation, value orientation, self-awareness, self-esteem, interaction with social environment, etc.) [16, p. 41].

We agree with the view that broadcasting as a central psychic function is carried out in close connection with cognitive, emotional and personal structures and provides a full-fledged human development (Ushakova T., 2001). That is why speech disorders, as a rule, are combined with violations of the integrative activity of the brain in the realization of mental processes, the perception of sensory information, processes of attention and memory.

Speech violations to some extent affect the various aspects of the child's life, reflected in its activities, behavior, on the physiological functions of the child's organism. In turn, all this negatively affects the formation of the letter.

Letter is a very complex developmental feature and is automated with the ripening of the brain. Structural and functional deviations in the central nervous system in violation of the letter (diction) create the basis for various forms of violations. Scientists note in children with a violation of writing difficulties in processing visual information, violations of auditory perception, violation of short and long-term memory, slow cognitive ability of speech processing, violation of analysis and synthesis, ability to decrypt and organize sound. Violations of the letter cause motor-spatial and temporal violations (I. Sadovnikova, V. Tarasun).

Language competence is a broad concept that encompasses a wide range of language abilities, knowledge, abilities and skills that provide speech activity (E. Sobotovich, V. Tarasun, and others). The expression of speech competence is the development of skills to use oral and written speech, the variety of means of expressiveness, in view of the purpose and objectives of the statement and sphere of public life.

Language, speech and communicative competences are correlated both in learning and in the real use of language carriers so that each of the following competences is provided by the previous one. It is believed that in the educational process the transition from the first competence to the second is possible through the development of speech operations, for which it is necessary to establish the 
proper proportion in the complex application of the system, functional and actually communicative approaches. Absolutism of the latter may slow down the education of at least the absolutism of any other approaches, and therefore the method should be flexible and diverse, as flexible and diverse language itself (Kondakova G. B., 2007).

The effectiveness of speech development of children greatly depends on taking into account the data of modern psychology, psycholinguistics and linguodidactics.

Problems of speech are of interest to speech therapists, logicians, literary critics, sociologists, physiologists, specialists in the theory of communication and informatics, as well as acoustics. Essential characteristics of speech are the subject of research in philosophy, psychology, pedagogy, neuropsychology, psycholinguistics, neurolinguistics, and others like that.

Today, broadcasting is seen as a complex, specifically organized form of conscious activity, which is always carried out by a complex functional system, that is, based on the work of the brain as a single body, each part of which makes its specific contribution to the organization of speech.

Having adopted the «The International Declaration on Higher Education for the XXI century: approaches and practical measures» (France, Paris, 1998), the participants of the UNESCO International Conference pointed to need to implement transdisciplinary approaches to educational programs and to train future professionals to use the transdisciplinary approach to solving complex problems. The international practice of using the transdisciplinarity of the learning approach is primarily due to the development of education for sustainable development.

In domestic science, the consideration of the transdisciplinary phenomenon, first of all, is associated with the unification of philosophical and technological grounds for solving anthropological problems; using a transdisciplinary system approach as a methodology for recognizing and studying a single ordered environment.

The set of ideas that underlies the transdisciplinary approach include:

- proclamation of complexity, multidimensionality, constant variability of the world;

- recognition of the ability of human consciousness to reflect in theoretical and practical experience the complexity and multidimensionality of the world;

- the affirmation of the principal complementarity of cognition forms and the need not only to combine the meanings that lie outside specific disciplines, but also to go beyond the boundaries of interdisciplinary and purely scientific forms of cognition;

- orientation towards the identification and practical solution of the most difficult life problems of importance to society, which by their nature can't be understood within the limits of only scientific knowledge;

- recognition of the right of wide public discussion of scientific information, strategically important for a society's life, and its scope.

Consequently, the prerequisites for expanding the application of transdisciplinary research strategies in pedagogical theory and practice are objectively existent. The use of this strategy makes it possible to influence the development of pedagogical knowledge ontologically and methodologically. At the level of ontology, science can open access to previously unknown sources of pedagogical phenomena and processes, and at the level of the methodology the emergence of a new level of understanding of pedagogical objects.

It should be emphasized that the transdisciplinary strategy of studying pedagogical phenomena has a great heuristic potential for solving problems in the field of education. In that way, particular, despite the fact that in recent years serious discoveries in microbiology, genetics, cybernetics, genetic engineering, the interaction of natural sciences with humanitarian, philosophy, and theology has been expanded; teachers (both practitioners and theorists) are somewhat uncertainly guided in the modern complex of knowledge about the structure of the human brain, the psyche, the mechanisms of information exchange with the environment. At the same time, in fields related to pedagogy, a view is already formed on the nature of man, which «is not interpreted in terms of any mechanistic, biological or psychological theory», but are considered «in a single human dimension», that is, having a transdisciplinary basis. As S. Bratchenko remarks, such an existential-humanistic view is «this look is deep, wise, you can even say, beautiful, but very difficult» [17].

Mechanisms for organizing cognitive experience at different stages of human life, of course, require transdisciplinary research to bring educational strategies in line with the fullness of human consciousness natural possibilities (brain, psyche). In spite of the fact that in modern scientific opinion 
there is no conventional point of view concerning the question of the relation of interdisciplinarity, multidisciplinarity and transdisciplinarity as research principles, all researchers who argue over terminological differences, combines the conviction that disciplinary limitations do not allow to form an integral an idea of most complex multi-level objects of research, including the person.

That is why, among the main trends of the modern education system, interdisciplinary integration of general didactics and pedagogical correction, which is not only an important means of development of the speech of primary pupils, but also requires changes in the organizational structure of the general education process, posing it as a systematic and innovative factor.

At the modern stage of the formation of speech therapy is quite clearly reflected its internally system, multi- and transdisciplinary links with other sciences. Proper organization and implementation of differential diagnosis using the considered approaches and addressing the issue of the main cause of speech development disorders is a rather difficult task. After all, the main task of diagnosis is a comprehensive identification of the nature of the pathology, its structure and individual manifestations of manifestation, which is the basis of the system of complex correctional work.

In this context, the relevance of the multi- and transdisciplinary approach is determined by many factors and, above all, by the factor of speech polymorphism. The underdevelopment of speech, according to O. Strebeliev, is a complex multimodal disorder of the speech mechanism, which inevitably leads to secondary disorders, which can manifest itself as an independent, primary form of speech pathology (for example, general underdevelopment of speech), and another form of abnormal child development (delay mental development, cerebral palsy, reduction or loss of hearing and many others). The underdevelopment of speech, according to the scholars, is the most common cause of school failure [18].

Today the point of view is quite popular and understandable due to the speech development of the underdeveloped speech of those scientists who consider the speech pathology from the multidisciplinary and transdisciplinary positions. In this approach, speech impairment is called systematical in the event that the «malfunction» of one of the system-forming links of the speech system leads to violations in the work of the entire speech mechanism in general.

Such a view of the essence of systemic speech disorders has evolved, of course, not by chance. It was the result of the integration of the most important achievements in the field of linguistics, psycholinguistics, psychology, didactics, and many others associated with speech therapy scientific disciplines.

The greatest need for assessing the problems associated with the same time, during which there were no additional parameters, one-time use, not necessary for the multidimensional logopedic character.

It should be noted that the practical application of multidisciplinary and transdisciplinary approaches in the study of speech development of children of the primary school age with dysgraphia is expedient and far-reaching, since in resolving the diagnostic problem, it is necessary to take into account the many known factors that are the subject of study of other disciplines (psychology, neuropsychology, neurolinguistics, psychophysiology, psycholinguistics, etc.). And because of it the discipline «complementary», that practical issues related to the acquisition of knowledge and it will be realized.

Such is a multidisciplinary and transdisciplinary early assessment, and our error, and productivity, and opportunities for successful and correct development. Creation of such an approach in modern system analysis methods, including in a mysterious situation, in which there are problems that are not related to each other.

The multidisciplinary and transdisciplinary approaches to metered development, the so-called «mistakes of diagnostics», impeccable reputation, the current situation in the country, including in all times in recent years not only the field of scientific knowledge, but also can't be the subject of research. The creation of new educational institutions, including new ones, has no fundamentally new, natural and theoretical and practical character.

Conclusions. Answering questions related to the complexity of activities and the correct retail of children's elementary school age disgraphy, which are important for the socio-cultural and social sphere. Considering the diversity of views to the essence of interdisciplinary, multidisciplinary and transdisciplinary approaches, we believe that the same value in the study of a child with a violated speech development is not only that they contribute to a greater depth of study of the object, but that the whistle allows create new formula of the problem and prospects for the new perspective of research work. 


\section{REFERENCES}

1. Nicolescu B. The transdisciplinary evolution of the university condition for sustainable development. [Електроний ресурс]. Режим доступу: http://ciret-transdisciplinarity.org/bulletin/b12c8.php

2. Piaget J. L'épistémologie des relations interdisciplinaires. Internationales Jahrbuch für interdisziplinäre Forschung. 1974. Vol.1. pp. 154-172.

3. Касавин И.Т. Дискурс-анализ как междисциплинарный метод гуманитарных наук // Эпистемология и философия науки. 2006. Т. Х. № 4. С. 7.

4. Книгин А.Н. Междисциплинарность: основная проблема // Вестник Томского государственного университета. Серия: Философия. Социология. Политология. 2008. № 3. С. 14-21.

5. Киященко Л. П. Феномен трансдисциплинарности - опыт философского анализа // Santalka. Filosofija. Vilnius, 2006. Т. 14. № 1. C.17.

6. Mittelstrass J. Interdisziplinarität oder Transdisziplinarität? // L. Hieber (ed.). Utopie Wissenschaft. Ein Symposium an der Universität Hannover über die Chancen des Wissenschaftsbetriebs der Zukunft (2122 November 1991). Munich-Vienna, 1993. S.17-31.

7. Киященко Л. П. Философия трансдисциплинарности. М.: ИФРАН, 2009. С. 23.

8. Князева Е. Н. Трансдисциплинарные стратегии исследований. Вестник Томского государственного педагогического университета. 2011. №10. С. 193-201.

9. Молчанов В.О науке, религии, системной философии Ю.А. Урманцева, трансперсональной психологии С. Грофа и формировании новой мировоззренческой парадигмы // Грани эпохи. 2013. № 53. C. $77-86$.

10. Хабермас Ю. Моральное сознание и коммуникативное действие. СПб.: Наука, 2000. С. 27-28

11. Nikiforov A. L. System and Informological Approach to Cognition and Practical Work. Moscow: New Centre, 1999. $140 \mathrm{p}$.

12. Жинкин Н. И. Механизмы речи // Заикание. М. : АПН РСФСР, 1958. С. 13

13. Глухов В. Психолингвистика. Теория речевой деятельности. М.: АСТ. 2007. 223 с.

14. Зимняя И. А. Основные линии психического развития ребенка // Эксперимент и инновации в школе. 2010. №2. C. 41

15. Леонтьев А. А. Слово в речевой деятельности. М.: URSS, 2006. С. 57 - 60.

16. Братченко С. Экзистенциальная психология глубинного общения. М: Смысл, 2001. 197 с.

17. Стребелева Е.А. Психолого-педагогическая диагностика нарушений развития детей раннего и дошкольного возраста. М.: ВЛАДОС, 2008. 129 с. 